\title{
GABCİKOVO-NAGYMAROS DAVASI
}

\author{
Gabcikovo-Nagymaros Case
}

Yrd. Doç. Dr. Şule Anlar GÜNEŞ*

\begin{abstract}
GİRIŞ, I.TUNA HAVZASININ ÖNEMI VE SINIRAȘAN SULARDA YARGISAL SÜREÇ, II.GABCIKOVO-NAGYMAROS UYUŞMAZLIĞININ GELIŞIIM SÜRECİ, III.UYUŞMAZLIĞIN SIYYASI KONULARLA BAĞLANTISI, A.Tuna Nehrinin Askeri Stratejik Önemi, B.Etnik Boyut, IV.ULUSLARARASI ADALET DIVANI ÇERÇEVESINNDEKİ GELİ̧̧MELER, A.Tahkimnamenin İçeriği ve Divan'ın Sorunlara Yaklaşımı, B.Ardıllık Sorunu Bakımından Divanın Tutumu, C.Rebus Sic Stantibus İlkesi Çerçevesindeki Değerlendirmeler, DEĞERLENDİRME ve SONUÇ
\end{abstract}

\section{ÖZET}

Macaristan ile Çekoslovakya arasında 1977 yılında yapılan andlaşma ile Tuna nehrinin bu iki ülke arasında aynı zamanda sınır oluşturan kesimi üzerinde, üç ayrı baraj ve ek tesisler yapılması kararlaştırılmıştı. Projenin uygulanmaya başlanmasından bir süre sonra Macaristan ekolojik nedenler ileri sürerek, projeyi önce askıya aldı, sonra da durdurdu. 1992 yılında da tek taraflı bildirimle 1977 Andlaşmasının sona erdiğini açıkladı. Projenin Çekoslovakya ayağında ise Gabcikovo barajının tamamlanmasının ardından, Varyant C etabı sonuçlandırılıp çalıştırılmaya başlandı. Macaristan ve Slovakya birbirlerinin yaklaşım ve eylemlerinin hukuka aykırı olduğunu ileri sürmekteydiler ve her iki tarafın dile getirdiği kaygılar içinde çevresel boyut öne çıkmaktaydı. Neredeyse silahlı çatışma noktasına kadar tırmanan gerginlik, Avrupa Topluluğu'nun arabuluculuğu

\footnotetext{
* Orta Doğu Teknik Üniversitesi İktisadi ve İdari Bilimler Fakültesi Öğretim Üyesi.
} 
neticesinde azaltılarak, uyuşmazlığın UAD (Uluslararası Adalet Divanı) önüne götürülmesi sağlandı. UAD nın, beklenen ölçüde irdelenmemiş olmakla birlikte, uluslararası çevre hukuku kavram ve ilkelerinin önemini kabul eden bir karar vermiş olması, bu davanın başlıca özelliğidir.

Anahtar Kelimeler: Uluslararası Adalet Divanı, Gabcikovo-Nagymaros davası, Slovakya, Macaristan, uluslararası çevre hukuku.

\section{ABSTRACT}

According to a bilateral agreement concluded by Hungary and Czechoslovakia in 1977, construction of three dams and additional installations over the section of the Danube which constitutes the natural boundary of these two states was targeted. After a short period upon the beginning of the implementation of the project, Hungary first suspended and then abandoned the project on the basis of ecological reasons and finally declared the termination of the 1977 Treaty in 1992. Concerning the Czechoslovakian part of the project, the Gabcikovo dam was completed and Variant $\mathrm{C}$ was put into operation subsequently. Both Hungary and Slovakia were accusing one and the other for their activities and environmental dimension was significant in both of the parties' expressed concerns. The tension which escalated to the point of armed conflict was relieved as a result of the mediation of the European Community and the submission of the conflict to ICJ (International Court of Justice). The significance of this case is the ICJ's recognition of international environmental law concepts and rules for the first time albeit it falls short in elaborating them.

Keywords: International Court of Justice, Gabcikovo-Nagymaros case, Hungary, Slovakia, international environmental law.

\section{GİRIŞ̧}

Gabcikovo-Nagymaros ${ }^{1}$ uyuşmazlığı Avrupa'nın ikinci uzun nehri olan Tuna ile ilgili çok sayıdaki uyuşmazlıktan sadece biri, ancak en ilginç olanıdır. Uluslararası Adalet Divanı (UAD) önüne götürülmeden önce Macaristan ve Çekoslovakya'yı uzunca bir süre sarsan bu sorun uzun yıllara yayılan, soğuk savaş sonrası Doğu-Avrupa'da siyasi rejimlerin değişmesine de tanıklık etmiş olan bir davadır. Sosyalist dönemde başlatılan ve bu dönemin bölgedeki büyük ölçekli en son projesi olarak bilinen GabcikovoNagymaros projesine ilişkin bu uyuşmazlık, Macaristan ve Çekoslovakya'da ortaya çıkan siyasi gerilimlerle paralel biçimde gelişen ve bir ölçüde bu devletlerde sosyalist dönemin son yılları ile demokrasinin ilk yıllarındaki siyasi süreçleri yansıtan bir özelliğe sahiptir.

\footnotetext{
${ }^{1}$ Gabcikovo Nagymaros metin içinde G-N olarak da anılmaktadır.
} 
Gabcikovo-Nagymaros Davası ${ }^{2}$, UAD nın uluslararası çevre hukuku kavram ve ilkelerini gözönüne alarak değerlendirme yaptığı ilk uyuşmazlık olarak gündeme gelmekle beraber, uluslararası hukukun daha birçok alanına ilişkin boyutlar içermektedir. Bu dava doğal kaynaklardan yararlanılırken koruma-kullanma dengesinin gözetilmesini gerektiren yönleriyle Çevre Hukuku ve Sürdürülebilir Kalkınma Hukuku, Tuna nehrinin kıyıdaş iki devlet arasında kullanımına ilişkin olması sebebiyle Sınıraşan Sular Hukuku, 1977 yılında Macaristan ile Çekoslovakya arasında yapılan bir sözleşmenin uygulanma sorununa ilişkin olması sebebiyle Uluslararası Andlaşmalar Hukuku, uyuşmazlığın taraflarından Çekoslovakya'nın zaman içinde bölünmesi ve dava konusu bölgenin Slovakya tarafında kalması boyutu ile Uluslararası Ardı1lı Hukuku gibi, uluslararası hukukun birbirinden tamamiyle farklı alanlarına yönelik unsurlar içeren çok yönlü ve karmaşık bir davadır. Avrupa çevre politikaları bağlamında gündemi neredeyse 20 yıl kadar bir süre meşgul eden bu uyuşmazlıkla ilgili olarak, UAD nın tüm bu hukuk dalları arasında yeni bir denge oluşturacak şekilde bir değerlendirme yapacağı konusunda, yüksek bir beklenti söz konusu olmuştur. 1997 yılında verdiği kararla, uyuşmazlığın her iki tarafının da, farklı noktalardan, uluslararası hukuku ihlal ettikleri sonucuna varan Divan'ın bu beklentileri istenilen ölçüde karşılamadığı görülmektedir. Bu çalışmada UAD kararına konu olan Gabcikovo-Nagymaros uyuşmazlığının çeşitli yönleriyle ele alınıp irdelenmesi amaçlanmaktadır.

\section{TUNA HAVZASININ ÖNEMI VE SINIRAŞAN SULARDA YARGISAL SÜREÇ}

Almanya'dan, Romanya'nın doğusuna kadar uzanan ve buradan Karadeniz'e dökülen Tuna nehri, 2, 860 kilometre (1,773 mil) boyu ile, Avrupa'nın ikinci uzun nehridir. Kolları da dahil onbir ayrı ülkeden geçen bu nehir, çok eski zamanlardan beri ulaşımda kullanılmakta, gerek endüstriyel ve tarımsal gerekse evsel tüketim için suyundan istifade edilmekte, üzerinde yapılan barajlar yoluyla elektrik enerjisi üretiminde kendisinden yararlanılmaktadır. Main ve Ren nehirlerine kanallarla bağlanması ile birlikte bu nehir Karadeniz'le Kuzey Denizi'ni bağlayan önemli bir ulaşım ağı haline gelmiştir ${ }^{3}$. Tuna nehri kıyıdaş devletlerin karşılıklı bağımlılı̆̆ını pekiştirecek ve işbirliği yapmalarını zorunlu hale getirecek yoğunluktaki kullanımıyla, bu devletlerin ticari ve ekonomik yaşamları üzerinde önemli bir rol oynamış olmakla birlikte, kalkınmanın

2 UAD nın uyuşmazlıkla ilgili kararı için genel olarak bkz. ICJ Reports of Judgements 1997, Case Concerning the Gabcikovo-Nagymaros Project, Hungary vs. Slovakia, (25 September 1997),http://www.icj-cij.org/icjwww/idocket/ihs/ihsjudgement/hs_ijudgement_970925.html (18 Kasım 1999 tarihi itibariyle).

ICJ Reports of Judgements 1997, paragraf (prg.) 16-17. 
bedeli Tuna için ağır olmuştur. Tuna nehri özellikle yirminci yüzyılın ikinci yarısından itibaren yoğunlaşan sanayi ve tarım faaliyetlerine, hızla artan nüfus baskısının da eklenmesiyle ağır bir ekolojik çöküntü içine girmiştir. Tuna'daki ağır çevre sorunları, sadece kendi havzasını değil, ölmekte olan denizler kategorisi içinde yer alan Karadeniz'i de son derece olumsuz etkilemektedir. Karadeniz'de, en önemli kirlilik kaynağı olan karakökenli kirliliğin \% 75inin Tuna havzasından kaynaklandığ1 ortaya konulmuştur. Karşı karşıya kalınan tehdidin olumsuz etkileri, Tuna'ya kıyısı olan devletlerin oluşturduğu, Tuna Çevre Komisyonu tarafından yürütülen eylem planı yoluyla bertaraf edilmeye çalışılmakta ve bu arada Karadeniz çevre komisyonu ile özel bir ortaklık protokolü yürütülmekte ise de, alınan önlemler sorunun büyüklüğü karşısında yetersiz kalmaktadır ${ }^{4}$.

Tuna'nın içinde bulunduğu durum, sınıraşan diğer bir çok nehir bakımından da geçerli olacak şekilde, kıyı devletleri arasında işbirliği ve dayanışmayı zorunlu kılar. Bu zorunluluk çevre sorunları bağlamında olduğu kadar, bu nehirden en ekonomik ve adil biçimde nasıl yararlanılması gerektiğinin belirlenmesi bakımından da önem taşır. Gabcikovo-Nagymaros uyuşmazlığı olarak uluslararası hukuk literatüründe yerini alan konu, işte esas olarak Tuna nehrinin ortak kullanımı, bu kullanımdan dolayı ortaya çıkan sorunlar ve bu sorunların çevresel etkileri ile ilgilidir.

Uluslararası hukuk uygulamasında sınıraşan sular ve bu bağlamda suyun doğal bir kaynak olarak tabi olacağı hukuk kuralları konusunda bugün gelinen noktada, örf adet kurallarının yanısıra ${ }^{5} 1997$ yılında imzaya açılmış olan Uluslararası Suyollarının Ulaşım-Dışı Amaçlarla Kullanılması Hukuku Sözleşmesi ile 1992 yılında BM Avrupa Ekonomik Komisyonu tarafından Helsinki'de imzaya açılan Uluslararası Göller ve Suyollarının Korunması ve Kullanılması Hakkında Sözleşme hükümleri önem taşır ${ }^{6}$. Uluslararası uygulamada sınıraşan sular kıyıdaş devletler arasında sıklıkla ihtilaf konusu olmakla beraber, sorunların yargı ve hakem süreçlerine yönlendirilmeleri

4 Güneş Şule (2001), "Karadeniz'de Çevresel İşbirliği, 1992 Bükreş Sözleşmesi", ODTÜ Gelișme Dergisi, Cilt 28, Sayı 3-4, s. 319 ve 323-325.

5 Uluslararası Su Hukukunun ilkeleri bağlamında mutlak ülkesel egemenlik, mutlak ülkesel bütünlük, sic utere tuo ut alienum non laedas gibi geleneksel ilkeler yanında; makul ve hakkaniyete uygun kullanım, çıkarların ortaklı̆̆ı, önceden ihbar ve iyiniyetli müzakere ilkeleri gibi yeni grup ilkelerin gelişmekte olduğu görülmektedir.

Eckstein G. (1995), "Application of International Water Law to Transboundary Groundwater Resources, and the Slovak-Hungarian Dispute Over Gabcikovo-Nagymaros", Suffolk Transnational Law Review, Vol. 19, s. 68-71.

6 BM Uluslararası Hukuk Komisyonu'nun özellikle 1997 yılında tamamlanan andlaşma metninin oluşturulması sürecinde önemli katkısı olduğu görülür. Andlaşmanın dikkati çeken özelliklerinden biri uyuşmazlıkların çözümlenmesine yönelik hakemlik uygulaması konusunda sözleşmeye ilave, ek bir sözleşmeye yer vermiş olmasıdır Türkiye bu sözleşmeye taraf değildir. Türkiye'nin sınırașan sular konusundaki yaklaşımlarının hukuki değerlendirmesi için bkz. Toluner Sevin. Milletlerarası Hukuk Açısından Türkiye'nin Bazı Dış Politika Sorunları, Beta Yayınları, 2000 İstanbul, s. 331-345. 
nadiren söz konusu olmaktadır ${ }^{7}$. Uluslararas1 yarg1 sürecine götürülen ve karara bağlanmıș olan sınırlı sayıda uyuşmazlık içinde Oder Nehri kararı ${ }^{8}$, Meuse Nehri Karar1 ${ }^{9}$ ile Lac Lanoux karar ${ }^{10}$ dikkat çekmektedir. UAD nın G-N kararında, doktrinde geliştirilen kavramlara başvurmanın yanısıra, özellikle USAD (Uluslararası Sürekli Adalet Divanı) tarafından ele alınmış olan Oder ve Meuse kararlarına, davanın değişik aşamalarında göndermeler yaptığı ve bu davalarda temeli atılan kavram ve ilkeleri geliştirerek, dayanak noktası olarak kullandığı görülmektedir. Ancak Gabcikovo-Nagymaros davasını öncekilerden ayıran başlıca özellik, bu davanın genç bir hukuk dalı olan uluslararası çevre hukukuna ilişkin kavram ve ilkelere ilk kez olarak yer vermesi ve bunun yanısıra, sınıraşan sularla ilgili olarak da UAD tarafindan ele alınan ilk uyuşmazlık olmasıdır ${ }^{11}$.

1993 yılında UAD nın önüne götürülen Gabcikovo-Nagymaros uyuşmazlığı, dört yıl süre ile Divan'ın gündemini meşgul etmiştir. Gabcikovo-Nagymaros davası kararının öne çıkan bir diğer özelliği, UAD tarihinde ilk kez olarak ${ }^{12}$ delillerin değerlendirilmesi amaciyla, uyuşmazlığa neden olan bölgeye inceleme ziyareti gerçekleştirilmiş olmasıdır. 1997 Nisan ayında davaya bakan tüm Divan üyelerinin katılımıyla gerçekleşen ziyaretin ardından, aynı yılın Eylül ayında karar verilmiştir. 1-4 Nisan 1997 tarihleri arasında Gabcikovo-Nagymaros proje alanına yapılan ziyarette, taraflarca görevlendirilen uzmanlardan bilgi toplanarak kayıtlara geçilmiştir. Olay yerinde inceleme yapmadan önceki döneme isabet eden 3-7 Mart 1997 ile

7 Higgins Rosalyn (2001), "Natural Resources in the Case Law of the International Court", Boyle Alan -Freestone David (eds.) International Law and Sustainable Development, Oxford University Press, s. 103.

8 Territorial Jurisdiction of the International Commission of the River Oder, (1929), PCIJ, Ser.A, No 23, 5

9 Diversion of the Water of the Meuse (Judgement), (1937), PCIJ, Ser.A/B, No 70, 4.

${ }^{10}$ Lanoux Gölü Davası Kararı için bkz., RIAA, vol.XII, Decision of 16 November 1957,.s. 285-317.

${ }^{11}$ Eckstein E. G., Eckstein Y. (1998), "International Water Law, Groundwater Resources and the Danube Dam Case", paper and presentation for International Association of Hydrologists XXVII Congress and Annual Meeting of the American Institute of Hydrology, Las Vegas (Sept.27-Oct. 2), Brahana et.al (eds.) Gambling with GroundwaterPhysical, Chemical and Biological Aspects of Aquifer-Stream Relations, s.245. http://www.internationalwaterlaw.org/Bibliography/Gabcikovo.html (12 Nisan 2006 tarihi itibariyle)

${ }^{12}$ Uluslararası uygulamada USAD görev yaptı̆̆ı dönemde, Meuse Nehri Davası görülürken de benzer bir uygulama yapılmıştır. Ancak Meuse davasında bu tarz bir yerinde inceleme ziyaretinin yapılmasını Belçika önermiş, Hollanda'nın da olumsuz bir tavır takınmaması neticesinde ziyaret gerçekleştirilebilmiştir. G-N uyuşmazlığında ise Slovakya ve Macaristan ortak bir irade ile bu ziyarete ev sahipliği yapmayı ve ziyaretin iyi komşuluk ilişkileri çerçevesinde geçmesi için gerekli olan ișbirliği ve koordinasyon ortamını sağlamayı üstlenmiş, UAD bunun üzerine 5 Şubat 1997 tarihinde, UAD statüsünün 44 ve 48 maddeleri ile Divan Tüzügü̈nün 31 ve 66. maddeleri uyarınca ziyaretin koşullarını düzenleyen kararnameyi kabul etmiștir. Tomka Peter, Wordsworth Samuel S., (1998), "The First Site Visit of the International Court of Justice in Fulfillment of Its Judicial Function", American Journal of International Law, Vol.92. No.1., s. 133-136. 
24-27 Mart 1997 tarihlerinde 10, inceleme ziyaretinden sonra 10, 11, 14 ve 15 Nisan 1997 tarihlerinde 4 olmak üzere, 14 uzman ve yetkilinin uyușmazlığa ilișkin sözlü iddiaları ve yöneltilen sorulara verdikleri cevaplar dinlenmiş ve UAD kararı, bu değerlendirmeler 1şığında nihai şeklini almıștır ${ }^{13}$.

Gabcikovo-Nagymaros uyuşmazlığ 1 ile ilgili olarak ortaya çıkan diğer önemli boyut çevre hukukuna gerek tarafların iddia ve savunmalarında, gerekse mahkemenin nihai kararında atfedilen önemdir. Bu dava ile birlikte USAD ve UAD nda doğal kaynaklara ilişkin olarak daha önceden bakılan davalarda görülen, “imtiyazlar" ve "doğal kaynakların kontrolü” gibi kavramlara odaklı yaklaşımlar yerlerini, "sürdürülebilirlik" ve "kaynak kullanımının sınırlandırılması" gibi kavramlara bırakmışlardır ${ }^{14}$.

\section{GABCIKOVO-NAGYMAROS UYUŞMAZLIĞININ GELİŞİM SÜRECI}

Macaristan ile Çekoslovakya arasında 1977 yılında imzalanan ve 1978 yılında onaylanarak yürürlüğe giren ortak yatırım projesi andlaşmasında ${ }^{15}$, Macaristan tarafında Dunakiliti barajı ve baraj gölü, Slovakya tarafında Gabcikovo baraj1 ve hidro enerji sistemi ve yine Macaristan'da Nagymaros mevkiinde baraj ve hidro enerji sistemi olmak üzere üç ayrı baraj inşa edilmesi ve ulaşımı düzenli hale getirmek üzere, mevcut nehir yatağının yapay olarak başka bir yöne çevrilmesi öngörülmekteydi. Proje her iki ülke bakımından da önemliydi. Yapılması öngörülen hidroelektrik santrallerinin, 1960larda gerek Macaristan gerekse Çekoslovakya'da kömür kullanımı nedeniyle giderek artan hava kirliliği sorunlarının azaltılması için uygun bir çözüm olacağı düşünülmekteydi. Bunun yanısıra özellikle Macaristan kesimindeki su taşkınlarının önlenmesi bu proje ile mümkün hale gelecekti. Üçüncü olarak da proje, Tuna-Ren-Main kanalının tamamlanması ve Karadeniz'le Kuzey Denizi hattının yoğun bir nehir ulaşımı için hazır hale getirilmesi anlamını taşımaktaydı.

Projenin 1986-1990 döneminde tamamlanmasına yönelik olarak, 1978 yılında çalışmalara başlandı. Ancak 1981 yılında mali kaynak yetersizliği ve çevresel sorunların farkedilmesiyle birlikte Macaristan'ın projeye bir süre ara verdiği görüldü. Çevresel nedenlere, projenin gerçekleştirilmesi için gerekli olan ekonomik kaynak sıkıntısı da eklenince, 1983 yılında bu sefer

${ }_{14}^{13}$ ICJ Reports of Judgements 1997, prg. 10, prg. 11.

${ }^{14}$ Higgins, s. 111

${ }^{15} \mathrm{Bu}$ belge metin içinde Andlaşma veya 1977 Andlaşması olarak da anılmaktadır. 1977 Andlaşması metni için bkz. The Treaty Between the People's Republic of Hungary and the Socialist Republic of Czechoslovakia on the Construction and Joint Operation of the Gabcikovo and Nagymaros System of Locks, Signed in Budapest on 16 September 1977, http://www.gabcikovo.gov.sk/doc/it1977en/treaty.html (12 Şubat 2006 tarihi itibariyle). 
tarafların birlikte karar vermeleriyle, enerji jeneratörlerinin çalıştırılması için hedeflenmiş olan 1990 yılı, 1995 yılına ertelendi. Bu dönemde başta bilim adamları olmak üzere, toplumun çeşitli kesimlerinden projeye yönelik itiraz sesleri yükselmeye başlamış, "Tuna Hareketi" olarak adlandırılan çevreci grubun öncülüğünde, bir dizi protesto eylemi başlatılmıştır. G-N projesinin yarattığ 1 ekolojik sorunlar içinde, Budapeşte içme suyunun \%65e yakın bir bölümünün sağlandığı yer altı sularının kirlenmesi ile Szigetkoz bölgesinde yer alan sulak alanlardaki biyoçeşitliliğin azalması başta gelmekteydi ${ }^{16}$.

Macaristan hükümeti 1986 yılında Avusturya ile yapılan kredi anlaşmasıyla, projenin önündeki mali engeli bir şekilde aşmaya çalışmış, ancak bu girişim projenin çevresel etkilerine yönelik itirazları bertaraf edememiştir. Macaristan'da çevrecilerin kısa zaman içinde örgütlenmesi ve muhalefetle birlikte hareket etmesi olgusu, Nagymaros Barajına yönelik kayg1 ve itirazları kısa zamanda siyasi gündemin temel konusu haline getirmişti. ${ }^{17}$ Nagymaros'a muhalefetin, genel olarak komünist rejime karş1 muhalefetle özdeşleştiği bu noktaya gelinmesinde, hükümetin de payı büyüktür. Hükümet 1985 yılında alternatif Nobel ödülü kazanan "Tuna Hareketi"ne vakıf olma izni vermemiş ve 1986 yılında düzenledikleri protesto eylemini polis marifetiyle engellemiştir. Hükümet benzer bir şekilde, Macaristan Bilim Akademisi ve Ulusal Çevre Koruma Kurumu gibi kendisine muhalefet eden kuruluşları, karar mekanizmalarından dışlamaktaydı ${ }^{18}$. Tüm bu baskıcı önlemlere rağmen Tuna hareketi, 1988 Eylül'ünde siyasi muhalefetin de desteği ile, Budapeşte'de 30,000 kişilik bir protesto yürüyüşü gerçekleştirmeyi başarmıştır ${ }^{19}$.

\footnotetext{
${ }^{16}$ Danube Dilemma, Hungary and Slovakia to Square Off at the Hague, s. 1-3. (http://greenhorizon.rec.org/bulletin/Bull64/cover.html (12 Nisan 2006 tarihi itibariyle).

${ }^{17}$ Macaristan'ın 1970lerde ve 1980lerde karşı karşıya kaldığı çevre sorunları, halkın bu konuya duyarlılığını arttırmıştı. Macaristan'da 1980'lerin ortalarına gelindiğinde. nüfusun neredeyse $\% 401$ hava kirliliği sorunu ile karșı karşıya olan bölgelerde yaşamaktaydı. Ülkedeki su kaynaklarının büyük bir çoğunluğu ciddi bir şekilde kirlenmişti. Yeraltı su rezervlerinin yüzde yetmişi ya kirlenmiş veya kirlenme tehlikesi ile karşı karşıya idi. 1987 yılında 3063 yerleșimin 800 kadarına temiz su sağlanması mümkün olmamaktaydı. Dolayısıyla G-N projesine yönelik olarak bilim adamları ve kanaat önderi çevrecilerin ileri sürdükleri iddiaların halk tarafindan benimsenmesi için zemin oldukça müsaitti. Fürst Heiko (2004), "The Hungarian-Slovak Conflict over the Gabcikovo-Nagymaros Dams: Analysis", Institute for Peace Research and Security Policy, University of Hamburg, Germany, s.3. http://www.internationalwaterlaw.org/Bibliography/Gabcikovo.html (30 Mayis 2006 tarihi itibariyle).

${ }^{18}$ Bu dışlamanın nedeni Macaristan Bilim Akademisi'nin 1983 yılında proje çalışmalarının durdurulmasını talep etmis olması, Ulusal Cevre Koruma Kurumu'nun ise projenin çevreye olası etkilerine yönelik bir analiz yapılmasını destekleyen tutumu idi. ibid., s. 4.

${ }^{19}$ Fuyana B., Madai F. (2001), "The Hungary-Slovakia Danube River Dispute:Implications for Sustainable Development and Equitable Utilization of Natural Resources in International Law", International Journal of Global Environmental Issues, Vol. 1, Nos.3/4, s. 331 .
} 
1989 ila 1990 yılları arasında Macaristan ve Çekoslovakya'da köklü siyasi değişiklikler olmuş ve işbaşına gelen hükümetler daha önce karşılaşmadıkları yepyeni sorunlarla başetmek durumunda kalmışlardı. Macaristan'da geniş çaplı muhalif gösteriler ve kampanyalar sonucu, Nagymaros'taki faaliyetler 1989 yılında işbaşına gelen sosyalist hükümet tarafından 13 Mayıs 1989 tarihinde askıya alınmıştır. Bu gelişme Çekoslovakya tarafından protesto edilmekle birlikte, bu itirazlar Macaristan'ın 27 Ekim 1989 tarihinde çalışmaları tamamıyla bırakma kararı almasına engel olamamıştır. Macar hükümeti ulusal programını açıklarken, Gabcikovo-Nagymaros projesinin tümüyle bir yanlışlık olduğunu ifade etmekten kaçınmamıştır. Aynı dönemde Çekoslovakya'da meydana gelen iktidar değişikliği sonucu devlet başkanı olan Vaclav Havel'de, Sovyet döneminin uzantısı olarak gördüğü projeyi "totaliter, doğaya aykırı ve dev bir proje" şeklinde nitelendirerek ağır bir şekilde eleştirmiştir. ${ }^{20}$ Bununla beraber Çekoslovakya'nın görece yoksul olan kesimi Slovakya için Gabcikovo baraj1 ulusal gurur sembolü olma özelliğini her zaman sürdürmüştür. Slovakya kesimi bir gün kazanacağı bağımsız devlet statüsü için, baraj projesini önemli bir güç kaynağı olarak görmüş ve projeye yönelik koruyucu bir tutum içinde davranmaya, her zaman özen göstermiştir ${ }^{21}$.

Projeye yönelik muhalif sesler yükselmekte ve bu sesler kitle hareketlerine dönüşmekle birlikte, gelinen bu noktadan geriye dönüş pek de mümkün görünmemekteydi. Kısmen Slovakya tarafinda kalan Dunakilidi $\% 90$, Gabcikovo ise \% 85 oranında tamamlanmıştı. Macaristan tarafında kalan Nagymaros'ta ise yapılması tasarlananların ancak küçük bir bölümü gerçekleştirilmişti ${ }^{22}$. Projedeki bu ilerlemeye rağmen Macaristan durumdan hiç te hoşnut değildi ve hükümet yoğun bir baskı ile karşı karşıyaydı. Bu siyasi atmosfer içinde Macaristan 1991 yılında, Slovakya'dan 1977 Andlaşmasını karşılıklı rıza ile sonlandırmalarına yönelik talepte bulundu. Talepte ileri sürülen temel iddia, Slovakya'nın bu projenin uzun vadedeki ekolojik etkilerini görmezden geldiği yönündeydi. Slovakya bu öneriye sert tepki gösterdi. Gabcikovo barajını inşa eden Slovakya su işleri kurumu başkanı Julius Binder, 12 yıldır emek harcanan projeye yapılan yatırımın bir milyar doları aştığını ve Macaristan'ın bu projeden elini kolunu sallayarak kurtulamayacağını ileri sürmekteydi ${ }^{23}$. Slovakya'dan beklediği desteği alamayan Macaristan, 19 Mayıs 1992 tarihinde, G-N Projesinin yer alt1

${ }^{20}$ ICJ Reports of Judgements 1997, prg. 38.

${ }^{21}$ Bostian Ida (1998), "Flushing the Danube: The World Court's Decision Concerning the Gabcikovo Dam", Colorado Journal of International Law and Policy, vol.9:2, s.413, not 120.

22 ICJ Reports of Judgements 1997, prg.31.

${ }^{23}$ Bostian Ida (1998), s. 409. 
suları, yerüstü suları ve yörenin genetik cessitliliği için büyük tehdit olușturduğunu ileri sürerek, 1977 Andlaşmasını tek taraflı olarak sonlandırdığına ilişkin açıklamasını yapmıştır ${ }^{24}$. Macar hükümeti ve parlamentonun bu kararı üzerinde Tuna hareketinin ve bilim çevrelerinin baskıc1 ve katı tutumlarının belirleyici bir rol oynadığ görülmektedir ${ }^{25}$. Macaristan bu kararını "ekolojik mücbir sebep", "sözleşme yükümlülüklerinin yerine getirilmesinin imkansız hale gelmesi" ve "sözleşme koşullarında köklü değişiklikler-rebus sic stantibus" gibi hukuksal gerekçelere dayandırmaktayd ${ }^{26}$.

Slovakya Macaristan'ın projeyi durdurma kararı aldığı noktada, projeye bu kez artık kendi başına ve kendi imkanlarıyla devam etme kararı alarak, C Varyantını devreye soktu. 1991 Kasım'ında başlayan hazırlık çalışmaları, Ekim 1992 de C Varyantının işler hale getirilmesi ve Gabcikovo barajında elektrik üretimine başlanmasıyla sürdürüldü. C Varyantı Tuna sularının Gabcikovo enerji santralini beslemesi amacıyla yönünün değiştirilmesine yönelik bir projeydi. Nehrin yönünün çevrilmesi, 1977 Andlaşmasında da yer alan bir konuydu ve esas olarak hem Macaristan hem de Slovakya'nın kıyıdaş olduğu Dunakiliti mevkii için planlanmıştı. Slovakya C Varyantını bu kez, her iki yakası da Slovakya'ya ait olan Cunovo mevkiinde gerçekleştirme kararı almış ve Macaristan'ın muhalefetine rağmen, Varyantı tamamlamıştı ${ }^{27}$.

Slovakya, Macaristan'ın 1989 yılında G-N Projesini bırakma kararı ile 1992 yılında 1977 Andlaşmasını tek taraflı olarak sona erdirmeye yönelik açıklamalarının, hukuksal yönden geçersiz olduğunu ileri sürmekte, ancak bu sefer de kendisinin tek taraflı olarak devreye soktuğu C Varyantı nedeniyle, Macaristan'ın tepkisini çekmekteydi. C Varyantı Tuna'nın akış yönünü neredeyse $\% 80$ oranında değiştiren, 30 mil uzunluğundaki beton kanal vasitasıyla Tuna'nın suyunun Gabcikovo barajına aktarılmasını sağlayan büyük bir projeydi. Barajın 16 mil kare ölçüsündeki rezervuar alanı, neredeyse 100 fite ulaşan derinliği, sekiz tribünlük enerji üretme kapasitesiyle devasa bir görüntüsü vard1 ${ }^{28}$. C Varyantının tamamlanması ile bu dev yapı devreye girmiş ancak buradan elde edilen enerjinin tümüyle Slovakya'ya verilmesi gibi dengesiz bir durum ortaya çıkmıştı. C Varyantından elde edilen ekonomik faydanın bölüşüm sorunu dışında, yol

${ }^{24}$ Declaration of the Government of the Republic of Hungary on the Termination of the Treaty Concluded Between the People's Republic of Hungary and the Socialist Republic of Czechoslovakia on the Construction and Joint Operation of the Gabcikovo and Nagymaros Barrage System, Signed in Budapest on 16 September 1977, May 19, 1992, International Legal Materials (1993), 32, 1247-1260.

${ }^{25}$ Fuyane-Madai, s. 331.

${ }^{26}$ ICJ Reports of Judgements 1997, prg. 92.

${ }_{28}^{27}$ Bostian, Flushing the Danube...., s.409.

${ }^{28}$ Eckstein (1995), s.77. 
açtığ1 ekolojik sorunlar da son derece rahatsız ediciydi. C Varyantının devreye girmesiyle birlikte Avrupa'nın en önemli sulak alanlarından biri olan ve barındırdığı yaklaşık 5000 farklı türle zengin bir biyoçeșitlilik alanı olan Szigetkoz bölgesi yok edilme tehlikesi ile karşı karşıya kalmıştı. Bunun yanısıra bölgedeki yeraltı su kaynakları yine C Varyantının devreye sokulmasıly birlikte, 1 ila 2 metre aşağıya düşmüş, bu durum birçok köy kuyusunun kurumasına yol açmıştı. C Varyantı mahkeme sürecine yansımamış olan etnik temelli bir gerilime de sebebiyet vermekteydi ${ }^{29}$.

Taraflar arasında giderek tırmanan gerginlik sonucu, uyuşmazlığın çıkmaza girmesi noktasında, Avrupa Topluluğu'nun (AT) arabuluculuğu gündeme geldi. 28 Ekim 1992 tarihinde Avrupa Topluluğu ile Macaristan ve Slovakya arasında sorunun çözümüne yönelik Londra Anlaşması adı verilen bir belge imzaland ${ }^{30}$. Ancak son derece karmaşık olan soruna, Avrupa Komisyonu'nun arabuluculuk süreçlerinin eklenmesi, durumu daha da karmaşık hale getirdi.Çözüm yolunda hiç bir ilerleme kaydedilememekteydi. İște bu noktada Avrupa Topluluğu'nun ikna çabaları sonuç verdi ve taraflar, içinden çıkamadıkları sorunu, UAD na götürme kararı aldılar. UAD ndan istenilen, eldeki somut verilere göre ve aslında her iki tarafın kendi açısından meşru olarak kabul edilebilecek fakat çelişen çıkarlarını dengeleyici nitelikte bir karar vermesiydi. Macaristan çevresel faktörleri, Slovakya ise ekonomik öncelikleri öne çıkarmaktaydı ${ }^{31}$. Divandan beklenen bu iki farklılığ uzlaştırmaya yönelik bir karar almasıydı.

\section{UYUŞMAZLIĞIN SIYYASİ KONULARLA BAĞLANTISI}

\section{A. Tuna Nehrinin Askeri Stratejik Önemi}

Avrupa çevre hareketi ve hukuku bakımından önem taşıyan bu davada mahkeme sürecine yansımayan ancak uyuşmazlıkla yakından ilgili, iki siyasi konu dikkati çekmektedir. Bunlardan birincisi uyuşmazlık konusu projenin, Sovyetler Birliği'nin Avrupa'nın batısını kontrol etmeye yönelik stratejik yaklaşımı ile bağlantısı, diğeri ise tarihin derinliklerinden bugüne taşınan Macaristan ile Slovakya arasındaki etnik gerginliğin, uyuşmazlık üzerine yansiyan etkileridir.

Soğuk savaş yıllarında Doğu Bloku ülkelerini kontrolü altında bulunduran Sovyetler Birliği için, nehir yolu taşımacılığında önemli bir yer tutan Tuna'nın, yılın oniki ayı etkin olarak kullanılması, diğer bir deyişle ulaşımın sürekliliği, önemliydi. Ancak Bratislava ile Budapeşte arasında

29 ibid.

${ }^{30}$ Fürst 5,6.

31 Projeye yönelik olarak Macaristan'ın genel tutumu "ekolojik merkezli" iken, Slovakya'nın yaklaşımı "tekno merkezli” idi ve bu iki yaklaşımında kendine göre meşruluk temeli mevcuttu. Önemli olan bu ikisini dengelemekti. Fuyane-Madai, 333-334. 
Tuna düzleşmekte ve bunun etkisiyle, bu kesimde ulaşım neredeyse yılda üç ay boyunca kesintiye uğramaktaydı. Geomorfolojik yapıdaki ani değişimin yarattığı bu sorunları azaltmadan, Tuna'da büyük ölçekli bir ulaşım imkanı oluşturmak mümkün değildi.

Tuna nehrindeki ulaşım sorunu ötedenberi kıyıdaş devletleri kaygılandırmaktaydı, Tuna Komisyonunun kuruluş amacı da zaten ulaşımı kolaylaştırmak ve nihai olarak Karadeniz ile Kuzey Denizi arasındaki su yolunu-Tuna-Main-Ren hattın kesintisiz hale getirmek suretiyle- tamamiyle açmakt1 $^{32} .1948$ yılında yapılan sözleşme örneğinde görüldüğü gibi, ulaşım koşullarını iyileştirmeye yönelik bazı adımlar atılmış ancak sorunun çözümünde başlıca öneme sahip tıkanıklık bu çabalarla aşılamamıştı ${ }^{33} .1977$ yılında Macaristan ile Çekoslovakya arasında yapılan andlaşma öncekine göre daha somut bir proje öngörmekteydi. Proje alanında bir dizi baraj inşa edilmesi yoluyla Tuna'nın bu kesiminde bir taraftan elektrik enerjisi üretilmesi imkanı doğarken, öte yandan nehir yönünün değiştirilmesi suretiyle ulaşım sorunu aşılmış olacak ve bu arada taşkınların önlenmesine yönelik teknik önlemlerin alınması da ihmal edilmeyecekti. Gerek bu Andlaşmada, gerekse bu andlaşmanın uygulanmasına ilişkin olarak ortaya çıkan tüm uyuşmazlık sürecinde öne çıkarılan esas boyut ekonomik olmakla birlikte, konunun askeri boyutunun da projenin oluşturulmasında önemli bir role sahip olduğu ileri sürülmektedir. Bu görüşe göre, Sovyetler Birliği 1977 yılında imzalanan projeyi ötedenberi tasarlamaktaydı ve projeye yönelik ilginin kökeninde açıkça ifade edilenler dışında, Karadeniz'den Batı Avrupa'ya uzanan bir nehir hattını, gerektiğinde askeri ve stratejik amaçlarla kullanma arzusu yatmaktaydı. Tuna nehrinde kesintisiz bir ulaşım olanağı, Sovyet savaş gemilerinin acil müdahale gerektiren durumlarda, batı Avrupa'ya doğru yönelerek durumu kontrolü altına almasını mümkün hale getirecekti ${ }^{34}$.

Uyuşmazlığın UAD çerçevesinde değerlendirilmesi esnasında konunun bu boyutu hiçbir aşamada gündeme getirilmemiş olmakla beraber, baraj projesi Sovyetler Birliğinin Doğu Avrupa'da esasında sona eren varlığını sürdürme çabasının bir uzantısı olarak görülmüş ve sistem muhaliflerinin yoğun tepkisini almıştır. Sisteme muhalefetin baraja muhalefetle neredeyse özdeşleştirildiği bu dönemde, 1977 Andlaşmasının Tuna'nın bu kesiminde ortaya çıkan doğal ulaşım engellerinin ortadan kaldırılmasına yönelik, Stalinci dönemin devlik merakının uzantısı olan askeri stratejik bir proje

\footnotetext{
${ }_{33}^{32}$ Fuyane-Madai, s. 330.

${ }^{33}$ Tuna Komisyonu bu sözleşme ile kurulmuştur. Sözleşme metni için bkz. Convention Regarding the Regime of Navigation on the Danube, August 18, 1948, UNTS 197.

${ }^{34}$ Stec Stephen, (1999), "Do Two Wrongs Make a Right? Adjudicating Sustainable Development In the Danube Dam Case", Golden Gate University Law Review, Vol. 29, s. 339 , not 76 .
} 
olduğu ve Sovyetler Birliği sistemi sona ermeden ve Doğu Bloku çökmeden önce tamamlanabilmiş olsayd1, Tuna Komisyonu'nda çoğunluğu ellerinde bulunduran Doğu Bloku devletlerinin, Macaristan'ın muhalefetine rağmen, Tuna nehrinin hemen tümünde etkinliklerini ve kontrollerini sürdürme olanağına sahip olacakları ileri sürülmüştür ${ }^{35}$.

\section{B. Etnik Boyut}

Gabcikovo Nagymaros uyuşmazlığında, dava sürecine yansitılmayan diğer boyut Slovak Macar etnik gerginliğidir. Uyuşmazlığın tırmanması ve tarafların uzunca bir süre soruna çözüm üretememelerine neden olan etnik gerilimin dinamiklerini irdelemek, Gabcikovo-Nagymaros uyuşmazlığını doğru bir çerçeveye oturtmak ve tarafların uzlaşıya varmak konusunda niçin bu denli zorlandıklarını anlamak bakımından anlamlıdır. Macaristan'da sosyalist rejimin değişmesine kadar olan dönem içinde, Gabcikovo Nagymaros uyuşmazlığına ilişkin olarak "çevre koruma" ve "sisteme yönelik protesto" unsurları dikkati çekmekte, sosyalist sistemin yıkılmasıla birlikte "azınlık politikaları" ve "iktidar mücadelesi" boyutlarının uyuşmazlık dosyasının unsurları haline geldiği, "sisteme yönelik protesto" unsurunun ise geçerliliğini yitirdiği görülmektedir ${ }^{36}$.

Slovakya yaklaşık 1000 yıl gibi bir süre Macaristan imparatorluğunun bir parçası olmuştur. Slovakya'nın Macaristan'dan ayrılma noktasında 200.000 kadar etnik Macar, Slovakya'nın buğday ambarı olarak anılan ve tam da 1977 Projesinin uygulama alanına isabet eden yerde bırakılmış ve zaman içinde bu kesim nüfusun \%11 ini oluşturacak olan 560.000 sayısına ulaşmıştı $^{37}$. Tüm ülkenin buğday ihtiyacının karşılandığ 1 , olağanüstü mümbit tarım arazilerinin bulunduğu bu bölge Gabcikovo projesinden, özellikle de projeye sonradan ilave edilen Varyant C uygulamasından son derece olumsuz bir şekilde etkilenmiştir. 1977 Andlaşması'nda Dunakiliti mevkiinde yapılması öngörülen yön verme çalışmaları, Slovakya'nın Varyant $\mathrm{C}$ adını verdiği uygulama ile Cunovo mevkiine kaydırılmıştı. Bu uygulama sonucu, kanal ile nehrin eski kesimi arasında kalan üç Macar köyü, Slovakya'nın geri kalan kesiminden koparılmıştı. Köylüler evlerinden çıkıp bir kilometre uzaklıktaki sağlık merkezi, kilise veya okullarına gidebilmek için, neredeyse 50 millik bir yol katetmek durumunda bırakılmışlardı. Bu durum yöre halkı üzerinde büyük hoşnutsuzluk yaratmaktaydı. Durum yapılan halkoylamasında net bir şekilde ortaya çıktı. Gabcikovo barajı ile ilgili olarak yapılan referandumda, Slovak kökenliler \%80 oranında projeyi desteklerken, Macar kökenli olanların \%90 oranında

\footnotetext{
35 ibid.

${ }^{36}$ Fürst, 11.

${ }^{37}$ Bostian, Flushing the Danube, s. 412.
} 
baraja karşı çıktıkları görüldü. Yörede ortaya çıkan gerilim giderek tırmanmakta ve neredeyse silahlı bir çatışma noktasına doğru gitmekteydi. 1992 Sonbaharında Slovakya sınırda askeri manevralara başlamış, gerek Slovak gerekse Macar politikacılar durumu körükleyici yaklaşımlar sergilemekten geri kalmamışlard ${ }^{38}$. Avrupa Topluluğu (AT) bu noktada duruma el koyma ihtiyacı hissetmiş ve AT na tam üyelik arifesinde olan bu iki ülkenin, çatışmayı bırakıp sorunlarını çözemedikleri takdirde, üyelik hayalinden vazgeçmeleri gerekeceğini bildirmiştir ${ }^{39}$. Tarafların uyuşmazlığ sevketmeleri beklenen UAD nın vereceği karara uyma konusundaki kararlılıklarının, AT ve NATO'ya kabul edilmelerinin belirleyici bir koşulu olduğu belirtilen bu açıklama, Gabcikovo-Nagymaros uyuşmazlığının da kaderini belirlemiş, böylece UAD na giden yol AT nin arabuluculuğu ve sürece müdahalesi sayesinde açılmıştı ${ }^{40}$.

\section{ULUSLARARASI ADALET DIVANI ÇERÇEVESINDEKI GELISSMELER}

\section{A. Tahkimnamenin İçeriği ve Divan'ın Sorunlara Yaklaşımı}

Macaristan ile Slovakya, 7 Nisan 1993 tarihinde imzaladıkları ve 28 Haziran 1993 tarihinde onay belgelerinin karşılıklı olarak değiştirilmesi suretiyle yürürlüğe giren, özel bir uzlaşı metni (tahkimname) ile uyuşmazlığ 1 UAD önüne götürmeye karar vermişler ${ }^{41}$ ve 2 Temmuz 1993 tarihinde UAD na sundukları mektupla süreci başlatmışlardır ${ }^{42}$. UAD süreciyle birlikte çok

\footnotetext{
${ }^{38}$ ibid.

39 AT çevre bakanları, 1990 yılında G-N projesine yönelik ÇED hazırlanmasını önermişler ve PHARE programı ile sağlanan destek çerçevesinde yeraltı sularının durumuna ilişkin bir çalışma gerçekleştirilmiștir. 1992 yllında Macaristan ve Slovakya AT nin arabuluculuğu üzerinde anlaşmaya vararak, 28 Ekim 1992 tarihinde dört maddelik Londra Anlaşmasını kabul etmişlerdir. Bunu takiben Avrupa Parlamentosu'nda konuya ilişkin kararlar alınmıştır. Londra Anlaşması'nın ilk iki maddesinin uygulanması Gabcikovo'dan elektrik üretimi yapılmaması anlamına geldiği gerekçesiyle, Slovakya Londra Anlaşmasını daha en baştan uygulayamayacağını ileri sürmüş ve nihayet 1992 Kasım ayında üçlü komisyonun Brüksel'de yaptığı toplantıda, uyuşmazlığın UAD na götürülmesi konusunda uzlaşmaya varılmıştır. UAD sürecinin başlatılmasının önkoşulu, tarafların su yönetimi konusunda geçici bir anlaşma yapmaları iken, bu konuda herhangi bir ilerleme söz konusu olmamıștır. 1993 Ocak ayında AT uzmanları tahkimname hazırlamışlar ancak Slovakya'nın direnciyle karşılaşmışlardır. Avrupa Parlamentosu'nun, esnek olması ve uzlaşmaya yönelik çaba harcaması yönünde Slovakya üzerinde uyguladığı bask1 sonuç vermiş ve Nisan 1993 de tarafların tahkimnameyi kabul etmeleri mümkün olabilmiştir. Avrupa Komisyonu, başlarda sadece teknik bir proje olarak algıladığı G-N projesinin, ne denli karmaşık ve hassas siyasi boyutlar içerdiğini ancak zaman içinde, bu deneyimler sonucu kavrayabilmiştir. Fürst, 6 .

${ }^{40}$ Schapiro Mark, (1997), "Unquiet Flows the Danube, Hungary Sues Slovakia Over Hydroelectric Project”, NATION, March 10 1997, Bastian'dan Naklen s. 413.

${ }^{41}$ Special Agreement for Submission to the International Court of Justice of the Differences Between the Republic of Hungary and the Slovak Republic Concerning the GabcikovoNagymaros Project, April 7, 1993,http://gw.ace.hu/ddg/haga/english/e spec.htm (11Mart 2006 tarihi itibariyle).

42 ICJ Reports of Judgements 1997, prg.1.
} 
boyutlu ve karmaşı bir görünüm içeren Gabcikovo-Nagymaros uyuşmazlığı, Divan'a yöneltilen sorular çerçevesinde, parçalara bölünmekte ve karmaşı bir siyasi uyuşmazlık basit bir hukuksal sürece indirgenmekteydi. Mahkeme, taraflar arasında uyuşmazlık konusu olan olayla ilgili olarak, kendisine yöneltilen bir dizi soruyu, hukuksal çerçeve içinde çözmek üzere görevlendirilmişti. Uyuşmazlığın UAD na yönlendirilmesi ile birlikte tarafların kendi aralarında yürüttüğü müzakereler, dışsal bir hukuksal sürece yerini bırakmıştı artık. "Prestij", "sembolik değer", "tarihsel antipatiler", "iktidar rekabeti” gibi uyuşmazlığın özüne ilişkin sorunların söz konusu bu hukuksal çerçevenin içinde ele alınıp değerlendirilmesi söz konusu ve mümkün değildił ${ }^{43}$.

Divan'dan çözümlemesi istenilen konular dört ana başlık altında toplanmaktadır. İlk üç soru, Macaristan ile Slovakya'nın uyuşmazlığın çeşitli boyutlarına yönelik olarak hukuki durumlarının tespitine yönelik iken, dördüncü olarak Divandan bu sorulara yönelik olarak vereceği kararlardan dolayı ortaya çıkacak hukuksal sonuçlarla ilgili tarafların hak ve yükümlülüklerini belirlemesi istenmektedir ${ }^{44}$. İlk üç soru bağlamında taraflar karş11ıklı olarak, projenin çevresel etkilerine yönelik iddialar ve karşıt iddialar ileri sürmüşlerdir. Ancak Divan, çevresel unsurlarla ilgili olaraktarafların haklı olup olmadıkları konusunda- bir karar vermekten kaçınmış, tarafların bu konuyu kendi aralarında müzakereler yaparak çözmelerini tavsiye etmiştir. Divan'a göre çevre alanında “....son yirmi yılda birçok belgede yer verilen, yeni norm ve standardlar gelişstirilmiştir. Devletlerin gerek yeni, gerekse eskiden bu yana devam eden faaliyetleri açısından bu yeni norm ve standardların dikkate alınması ve bunlara gereken ağırlı̆̆ın verilmesi gereklidir. Bu durum ise kısaca Sürdürülebilir Kalkınma kavramı olarak ifade edilen, ekonomik kalkınmanın, çevre koruma ile uzlaştırılmasını gerektirir..... Bu davanın amaçları açısından bunun anlamı, tarafların Gabcikovo enerji santralinin çalıştırılmasının çevresel etkilerinin ne olduğunu birlikte yeniden ele almalarıdır" Dolayısıyla Divan taraflara sorunun çözümüne yönelik reçete sunmaktan çok, görevlerini hatırlatır bir yaklaşım sergilemektedirr ${ }^{45}$.

Divandan ilk olarak, Macaristan'ın 1989 yilında GabcikovoNagymaros projesine ilişkin faaliyetleri askıya alma ve durdurma konusunda hukuksal yetkisi olup olmadığına yönelik bir karar vermesi istenmiştir. Macaristan 1989 yılında Gabcikovo-Nagymaros projesini askıya alma ve durdurma kararının "ekolojik zorunluk”tan kaynaklandığını ileri sürmüş ve

\footnotetext{
${ }^{43}$ Fürst, s. 6.

${ }_{45}^{44}$ bkz. Special Agreement, madde 2, paragraf 1 ve paragraf 2.

45 ICJ Reports of Judgements 1997, prg. 140.
} 
bu konudaki teknik sebepleri tek tek açıklamıştır ${ }^{46}$. Slovakya ise buna karş1 çıkarak, uluslararası andlaşmalar hukukunda andlaşmaların sona erme şartları arasında "ekolojik zorunluluk" şeklinde bir koşulun yer almadığını, zaten olayda da "ekolojik zorunluluk durumu" nun ne 1989 da ne de daha sonraları söz konusu olmadığını ileri sürmüştür. Slovakya daha da ileri giderek "ekolojik zorunluluk durumu" olayda mevcut olsaydı bile, bu kavramın hukuka aykırılı unsurunu bertaraf etme etkisinin sadece uluslararası sorumluluk hukuku bakımından geçerli olacağını, uluslararası andlaşmalar hukuku bakımından bir etki doğurmayacağını, dolayısıyla uluslararası bir sözleşmeden kaynaklanan yükümlülüğü ortadan kaldırmayacağını iddia etmiştir. Slovakya'ya göre Gabcikovo-Nagymaros projesinde bazı ekolojik sorunlar ortaya çıkmış olabilir ancak bunlar "ekolojik zaruret hali" teşkil edecek surette bertarafı mümkün olmayan sorunlar değildir. Macaristan'ın dayandığı zorunluluk hali, uluslararası bir andlaşma yükümlülüğünün askıya alınması için gerekçe teşkil edemez. Dolayısıyla Macaristan'ın 1989 yılındaki durdurma ve bırakma kararı, 1977 Andlaşması'nın 27. madde hükmünün ihlali anlamına gelmektedirr ${ }^{47}$. Karar metninin 27. ila 57. paragrafları arasında da görülebileceği şekilde, birinci soruya ilişkin olarak tarafların karşılıklı iddia ve savunmaları alınmış ve Divan Macaristan'ın 1989 yılında gerçekleştirdiği askıya alma ve durdurma eylemlerinin, 1977 Andlaşması'nın dolayısıyla uluslararası hukukun ihlali anlamına geldiğini ve bundan dolayı sorumlu tutulacağını karara bağlamıştır ${ }^{48}$.

UAD ndan ikinci olarak Slovakya'nın Varyant $C$ yi yürürlüğe koymak ve işletmek konusunda hukuksal yetkiye sahip olup olmadığ karar vermesi istenmektedir. Çek ve Slovak Federal Cumhuriyeti Kasım 1991'de Varyant C yi geçici çözüm olarak başlatmış, Ekim 1992'de ise uygulamaya koymuştur ${ }^{49}$. Divan kararının 60 ila 88. paragrafları bu sorunun irdelenmesine ayrılmıştır. Macaristan, Slovakya'nın C Varyantını uygulamaya sokarak, 1977 Andlaşmasını açık bir şekilde ihlal ettiğini, bununla da kalmayarak, bu eylemi ile 31 Mayıs 1976 yılında Budapeşte'de yapılmış olan "Sınır Sularında Su Yönetimi Sorunlarının Düzenlenmesine İlişkin Andlaşma" hükümleri başta olmak üzere diğer uluslararası yükümlülüklerini de ihlal etmiş olduğunu ileri sürmektedir ${ }^{50}$. Slovakya ise Macaristan'ın 1977 Andlaşması'ndan doğan yükümlülüklerini yerine getirmemesi olgusu karşısında, C Varyantının devreye sokulmasının

46 ibid., prg. 40.

471977 Andlașmasının 27. maddesi “tarafların sözlesme ile ilgili konularda öncelikle uyuşmazlıkların barışçıl yollarla çözümlenmesi mekanizmalarına gitmeleri gerektiğini öngörmektedir. ICJ Reports of Judgements 1997, prg. 45.

48 ibid., prg. 57.

49 ibid., prg. 60.

50 ibid. prg. $70-71$. 
ekonomik ve ekolojik gerekçelerle zorunluluk haline geldiğini, dolayısıyla bunun Slovakya açısından sadece bir yetki değil, 1977 Andlaşması bakımından hukuksal bir yükümlülük olduğunu ileri sürmektedir. Slovakya'nın iddiasına göre C Varyantı "geçici bir çözüm olarak" ve "ekolojik gerekçelerle" yürürlüğe konulmuş olan ve 1977 Andlaşmasına "mümkün olan en yaklaşık uygulama"dır ${ }^{51}$.

UAD na göre, Macaristan'ın 1989 yılından itibaren sürdürdüğü tutum, Çekoslovakya bakımından çeşitli güçlüklere yol açmış olmakla birlikte, 1977 Andlaşması'nın temel özelliği, andlaşmanın 1. 8. ve 10. madde hükümlerinde de açıkça belirtildiği üzere, "ortak bir yatırım projesi" olmasıdır $^{52}$. Bunun anlamı projenin tüm unsurlarının bir bütün, tek bir birim teşkil edecek şekilde, birbirinden ayrılmaksızın, eşgüdüm anlayışına uygun olarak işletilmesi ve kullanılması zorunluluğudur. Dolayısıyla projeye ilişkin kararların ortaklaşa alınması ve proje üzerinde ortak bir iyelik tesis edilmesi zorunludur. Çekoslovakya-daha sonra Slovakya, Varyant C uygulamasına yönelik olarak tek taraflı bir tutum içinde karar almış ve uygulamıştır. Bunun da ötesinde alınan karar uyarınca Tuna'nın yönü değiştirilmiş ancak bu değişiklik projenin orijinalinde birlikte kararlaştırılmış olan yerde değil, çok farklı bir mevkide gerçekleştirilmiş ve hepsinin de üstünde Varyant $C$ nin işletilmesinden kaynaklanan ekonomik kazanç yalnızca Slovakya'nın yararına ayrılmışıır ${ }^{53}$. UAD C Varyantına ilişkin olarak verdiği kararda, Slovakya'nın tek taraflı girişiminin ve bu girişim sonucu elde ettiği enerjiyi sadece kendi kullanımına tahsis etmesinin, uluslararası hukukun ihlali anlamına geldiğini ve Slovakya'nın verdiği zararları tazmin etmesi gerektiğini karara bağlamıştır. Divana göre Varyant C, 1977 Andlaşma hükümlerinin uygulanması değil, tam aksine, açık ihlalidir. Ancak Divan, Varyanta yönelik çalışmaların Slovakya kesiminde sürdürüldüğü ve taraflar anlaşabilselerdi sonlanması mümkün olan Kasım 1991-Ekim 1992 arasındaki döneme isabet eden faaliyetlerin, Slovakya açısından hukuka aykırılık unsuru taşımadığın $1^{54}$, Slovakya'nın hak ihlalinin ve uluslararası hukuk bakımndan sorumluluğunun, C Varyantının çalıştırılmaya başlandığ Ekim 1992 tarihinden itibaren söz konusu olmaya başladığını hükme bağlamıştır ${ }^{55}$.

51 ibid. prg. 67-69.

52 ibid. prg. 72.

53 ibid. prg. 76,77 ve 78 .

${ }^{54}$ Divanın C Varyantının hazırlık çalışmaları dönemi ile Varyantın bilfiil devreye sokulduğu dönem arasında fark gözeterek, Slovakya bakımından uluslararası hukuk ihlalinin, Kasım 1991-Ekim 1992 dönemde değil, Ekim 1992 den sonraki dönemde söz konusu olduğu seklindeki yaklaşımı, doktrinde kararın zayıf taraflarından biri olarak gösterilmekte ve eleştirilmektedir. Bostian, (1998), Flushing the Danube, s. 418.

${ }_{55}$ ICJ Reports of Judgements 1997, prg. 88. 
UAD, Slovakya'nın C Varyantına ilişkin uygulamasının, Macaristan'ın 1977 Andlaşmasını ihlal etme fiiline misilleme teşkil ettiği, dolayısıyla hukuka uygun olduğu görüşünü reddederek, Macaristan'ın hukuka aykırı hareketine karşı Slovakya tarafından orantısız bir şekilde zarar verilmesinin meşru olarak kabul edilemeyeceği, dolayısıyla Slovakya'nın hukuka uygunluk sebeplerinden yararlanamayacağını ileri sürmektedir ${ }^{56}$. Macaristan'ın 1989 yılındaki projeyi durdurma ve bırakma eyleminin 1977 Andlaşmasının ihlali anlamına gelmekle beraber, Macaristan'ın bu ihlalinin, onun Uluslararası Suyolları Hukukundan doğan, doğal kaynaklardan adil ve eşit bir yararlanma hakkını haleldar etmeyeceğini dolayısıyla, Slovakya'nın C Varyantını devreye sokması sebebiyle Macaristan'a verdiği zararların tazmin edilmesi gerektiğini hükme bağlamaktadır.

UAD ndan üçüncü olarak tahkimnamenin 2.madde, 1.paragraf $\mathrm{c}$ bendi gereğince Macaristan'ın 19 Mayıs 1992 tarihinde 1977 Andlaşması'nı tek taraflı olarak sona erdirmeye yönelik bildiriminin, hukuksal yönden geçerli olup olmadığını karara bağlaması istenmiştir. Divan kararının 89 ila 115. paragraflarının ayrıldığı bu sorun, dava esnasında UAD nı en çok meşgul eden konu olmuştur.

Davanın üçüncü soruya yönelik bu aşamasında, tarafların uluslararası çevre hukukuna ilişkin ilkeler konusunda, karş1lıklı olarak görüşlerini dile getirdikleri görülmektedir. Macaristan, uluslararası çevre hukukunun gelişmekte olan ilkelerinin, 1977 Andlaşması'ndan doğan yükümlülüklerini yerine getirmeye engel teşkil ettiğini, bu nedenle Andlaşma'yı feshetmek durumunda kaldığını ileri sürmektedir ${ }^{57}$. Macaristan'ın iddiasına göre, uluslararası hukukta mevcut olan "başka bir devletin ülkesine önemli zarar vermeme yükümlülüğü" şseklindeki ilke, ihtiyat ilkesinin gereklerine uygun bir şekilde,"erga omnes" nitelik kazanarak "zararı önleme yükümlülüğü ilkesine" dönüşmüştür ${ }^{58}$. Slovakya ise bu iddiaya karşı çıkarak, uluslararası çevre hukukunda, 1977 Andlaşması'nın uygulanmasına engel teşkil edecek jus cogens niteliğinde normlar olmadığını, Macaristan'ın kendisini 1977 Andlaşması'nı feshetmeye yetkili görmesinin, uluslararası andlaşmalar hukuku çerçevesinde değil, kendi kendine yardım veya zararla karşıllk kuralları bağlamında değerlendirilmesi gerektiğini ileri sürmüştür ${ }^{59}$. Divan bu noktada, 1977 Andlaşması'nın çevre korumaya yönelik hükümlerinin genel ve gelişime açık hükümler olduğunu belirtmekle yetinmiş, uluslararası çevre hukukunda zaman içinde ortaya çıkan yeni kavram ve ilkelerin neler

\footnotetext{
${ }_{57}^{56}$ ibid., prg.. 85.

${ }^{57}$ ICJ Reports of Judgements 1997, prg. 97.

58 ibid. prg. 97.

59 ibid. prg. 97.
} 
olduğunun tespitini yapmaktan kaçınmıştır ${ }^{60}$. Divan bu tespitin yapılmasının, Slovakya ile Macaristan'ın ortak sorumluluğu olduğunu, iyiniyetli bir müzakere süreci ile bu ilkelerin, 1977 Andlaşma rejimi bünyesine dahil edilmesinin mümkün olduğunu, 1977 Andlaşması'nın ilgili hükümlerinin buna engel teşkil etmediğini karara bağlamıştır ${ }^{61}$.

Macaristan, 1977 Andlaşması'nı tek taraflı olarak sona erdirmeye yönelik bildiriminin hukuka uygunluğunu gerekçelendirmek üzere, "zaruret hali", "andlaşma yükümlülüklerinin yerine getirilmesinde imkansızlık", "andlaşmanın Çekoslovakya tarafindan ihlal edilmiş olması", "uluslararası çevre hukukunda yeni normların ortaya çıkması" ve "andlaşma koşullarında köklü değişiklikler" (Rebus sic stantibus) gibi gerekçeler ileri sürerken ${ }^{62}$, Slovakya tüm bu iddiaları çürütmeye yönelik, karşıt iddialar geliştirmiştir. Divan'ın nihai kararında, Macaristan'ın 1977 Andlaşması'nı tek taraflı olarak sona erdirmeye yönelik açıklamasının hukuksal dayanağı olmadığına ve geçersizliğine karar verilmiştir. Divan' a göre, Macaristan'ın, C Varyantı nedeniyle Slovakya'ya karşı geliştirmiş olduğu tepki "hukuksal yönden meşruluğu olmayan", "erken bir girişim"dir. Slovakya'nın C Varyantı dolayısıyla ortaya çıkan sorumluluğu Ekim 1992 itibariyle başlamıştır, Kasım 1991-Ekim 1992 döneminde, Slovakya'nın Varyant çalışmalarından dolayı Macaristan'a karş1 uluslararası sorumluluğu söz konusu değildir. Macaristan'ın 19 Mayıs 1992 tarihinde yaptığı fesih bildirimi, Slovakya'nın uluslararası sorumluluğunun henüz ortaya çıkmadığı bu döneme isabet eden erken bir tepkidir, hukuka uygunluk sebebi teşkil edemez ${ }^{63}$.

\section{B. Ardıllık Sorunu Bakımından Divanın Tutumu}

Gabcikovo-Nagymaros davasında taraflar bakımından çözümlenmesi gereken sorunlardan biri, Macaristan ile o dönemdeki Çekoslovakya arasında yapılan 1997 Andlaşması'nın, Çekoslovakya'nın siyasi varlığının sona ermesiyle birlikte ardıllık hukuku kuralları bakımından sonuçlarının ne olacağının belirlenmesidir. Bir devletin hukuksal varlığının sona ermesi, o devletin daha önce diğer devletlerle akdetmiş olduğu andlaşmaların hukuksal etkilerinin ne olacağı sorusunu da beraberinde getirmektedir. Bu bağlamda bir devletin, hukuksal varlığı sona eren diğer bir devlete ardıl olup olamayacağı ve böylece önceden akdedilmiş olan andlaşmaların hukuksal

${ }^{60}$ Divan'ın uluslararası çevre hukukundaki kavram ve ilkelerin neler olduğunu irdelemekten kaçınması, bu dava nedeniyle ortaya çıkan yüksek beklentiyi karşılamak konusunda tereddüt içinde olduğunu göstermektedir. Divan'ın uluslararası çevre hukukunun örf adet ilkelerinin neler olduğunu irdeleme ve belirleme gibi önemli bir olanağı değerlendirmekten kaçınan tutumunun eleştirisi için bkz. Bostian, s. 420.

${ }_{62}^{61}$ ICJ Reports of Judgements 1997, prg.112.

62 ibid., prg. 92.

${ }^{63}$ ibid. prg 108 ve prg. 115 Divanın C Varyantına ilişskin olarak ikili yaklaşımın eleştirisi için bkz. Bostian Flushing the Danube, s. 418. 
geçerlilik durumları, geçerli olurlarsa andlaşmanın taraflarının hukuksal statüleri gibi sorunların çözümlenmesi gerekmektedir. Ardıllık kategorik olarak üç farklı çerçevede gündeme gelebilmektedir. Birincisi, bir devletin hukuksal kişiliğinin sona ermesinin üzerinden iki ya da daha çok devletin ortaya çıkması durumu, ikincisi, iki ya da daha çok devletin birleşmesi durumu, üçüncüsü ise, bir ülke parçasının bir devletten ötekine el değiştirmesi durumudur ${ }^{64}$. Uygulanacak hukuk kuralları bakımından da ardıllık konusunda ötedenberi uygulanan uluslararası örf ve adet hukuku ilkeleri yanında, 1978 tarihli Viyana Devletlerin Andlaşmalara Ardıl Olması Sözleşmesi hükümlerinin gözönünde bulundurulması gerekmektedir ${ }^{65}$.

Gabcikovo-Nagymaros uyuşmazlığına konu olan olaylar zinciri, Doğu Bloku'nun çöküşüne sahne olan tarihsel kırılma dönemine isabet etmektedir. 1977 yılında akdedilen Andlaşma ile uyuşmazlığa konu olan projenin yapılması kararını alan taraflardan Çekoslovakya 1. Dünya Savaşı'nın ertesinde kurulmuş, 2. Dünya Savaşı sonrasında ise Sovyetler Birliği'nin etkinlik alanı içindeki Doğu Bloku'na dahil olmuştur. Sovyetler Birliği'nin dağılması ve Doğu Bloku'nun çökmesi üzerine parçalanma sürecine giren Çekoslovakya, 1990 yılının Nisan ayında Çek ve Slovak Federal Cumhuriyeti adıyla önce federal bir devlete dönüşmüş, 1992 yılının sonunda ise varlığ1 sona ermiştir. 1 Ocak 1993 tarihi itibariyle Çek Cumhuriyeti ile Slovak Cumhuriyeti iki ayrı devlet olarak kurulmuşlardır ${ }^{66}$.

Gabcikovo-Nagymaros uyuşmazlığında, 1977 yılında Çekoslovakya ile Macaristan arasında yapılmış olan Andlaşma'ya ardıllık sorunu bağlamında, Slovakya ile Macaristan farklı iddialar ileri sürmüşlerdir. Slovakya'nın 1977 Andlaşması'nın ardılı olduğu iddiasına, Macaristan karşı çıkmıştır. UAD ise kararında Slovakya'nın tezini doğrulamış ve 1977 Andlaşması'nın ülkesel alana ilişkin bir sözleşme olması nedeniyle, uluslararası ardıllık hukuku ilkeleri gereği otomatik ardıllığın söz konusu olduğunu, dolayısıyla Slovakya'nın 1 Ocak 1997 tarihi itibariyle bu Andlaşma'nın ardılı haline geldiğini hükme bağlamıştır ${ }^{67}$.

\section{Rebus Sic Stantibus İlkesi Çerçevesindeki Değerlendirmeler}

Macaristan 1977 Andlaşması'na yönelik itirazlarına ve andlaşmanın karşılıklı rıza ile sonlanmasına ilişkin Slovakya'ya karşı yapmış olduğu çağrıya yanıt alamayınca, 19 Mayıs 1992 tarihinde Andlaşmayı tek taraflı

\footnotetext{
${ }^{64}$ Pazarcı Hüseyin, (1999) Uluslararası Hukuk Dersleri, III.Kitap, Gözden Geçirilmiş 3.bask1, ${ }_{55}$ Ankara, Turhan Kitabevi, s. 25 vd.

${ }^{65}$ ibid.

${ }^{66}$ Major Events in Slovak History, http://www.slovakia.org/history-summary.html (20 May1s 2006 tarihi itibariyle).

${ }^{67}$ ICJ Reports of Judgements 1997, prg, 123-124.
} 
olarak feshettiğini bildirmiştir. Bu bildirimin gerekçeleri içinde "zaruret hali", "andlaşma yükümlülüklerinin yerine getirilmesinde imkansızlık", "andlaşmanın Çekoslovakya tarafindan ihlal edilmesi", "uluslararası çevre hukukunda yeni normların ortaya çıkması" nın yanısıra, "andlaşma koşullarında köklü değişiklikler" (Rebus sic stantibus) ${ }^{68}$ ilkesinin de dayanak yapıldığı görülmektedir ${ }^{69}$. Divan, Macaristan'ın ileri sürdüğü “rebus sic stantibus" konusunda derinlemesine bir değerlendirme yapmaktan kaçınmış ve analizini 1977 Andlaşması'nın kendi dar teknik ve ekonomik çerçevesi içinde ele alma yolunu tercih etmiştir. Projenin büyük ölçüde soğuk savaş döneminin çıkar ilişkileri ve varsayımları üzerine inşa edilmiş olması, Sovyet himayesinin ortadan kalkmasıyla birlikte projeye yönelik algılama değişikliği, pazar ekonomisine geçiş, demokratikleşme, geopolitik gelişmeler, etkisi giderek yükselen çevre hareketi gibi unsurların dava üzerindeki olası etkileri, Divan tarafından dikkate alınmamıştı ${ }^{70}$.

Macaristan 1977 Andlaşması yapıldıktan sonra ortaya çıkan ve tarafların Andlaşmaya bağlılıklarını temelden sarsacak olan nedenler arasında "siyasi düzeyde meydana gelen değișmeleri" gerekçe olarak göstermektedir ${ }^{71}$. Bu iddiaya göre 1977 Andlaşması'nda esas olan amaç "Sosyalist Bütünleşme"dir, ancak bu amaç sosyalist bloğun çöküşü ile birlikte ortadan kalkmış, etkisini yitirmiştir. UAD Macaristan'ın bu gerekçesinin Andlaşma'nın feshi için geçerli olamayacağını ileri sürmüştür. Divan'a göre 1977 Andlaşması'nın yapılması üzerinde, o dönemin siyasi koşullarının doğal bir etkisi söz konusu olmakla beraber, projede öngörülen amaç enerji üretimi, ulaşımın iyileştirilmesi ve taşkınların kontrolü için ortak bir teknik yatırım projesinin gerçekleştirilmesidir. Dolayısıyla, Andlaşma yapıldığı esnada taraf iradelerinin oluşması üzerindeki itici güç siyasi olmaktan çok ekonomik niteliktedir. UAD nın bu konuyla ilgili olarak vardığ 1 sonuç, "o döneme hakim olan siyasi ortamın nitelikleri ile projenin temel amaç ve işlevinin çok da sıkı bir ilişki içinde olmadığı" dolayısıyla "siyasi ortamda" meydana gelen değişikliğin andlaşma koşullarında köklü değişiklik olarak yorumlanamayacağ 1 şeklindedir ${ }^{72}$.

\footnotetext{
${ }^{68}$ Uluslararası hukuk literatüründe, "Şartların Esaslı Şekilde Değişmesi” "Andlaşma Koşullarında Köklü Değișmeler" olarak yer alan rebus sic stantibus ilkesi, uluslararası bir andlaşmanın yapılması esnasında, tarafların iradesine esas olan koşulların, esaslı şekilde değișmesi halinde, sözleșmenin sona erdirilmesini veya sözleşmeye ilişkin taahhütlerin yerine getirilmemesini olanaklı kılan bir kavramdır. Pazarcı Hüseyin, (2001) Uluslararası Hukuk Dersleri, I..kitap, Gözden Geçirilmiş 9. baskı, Turhan Kitabevi, Ankara, s. 197.

${ }^{69}$ ICJ Reports of Judgements 1997, prg. 92.

${ }^{70}$ Stec S., Eckstein E.G., (1997), "Of Solemn Oaths and Obligations: The Environmental Impact of the ICJ's Decision in the Case Concerning the Gabcikovo-Nagymaros Project", Yearbook of International Environmental Law, Volume 8, Clarendon Press, 1998, s. 43.

71 ibid., prg. 95

72 ibid., prg. 104.
} 
Macaristan çevreye ilişkin bilgilerin değişmiş olması ve buna paralel olarak uluslararası cevre hukukunda yeni norm ve prensiplerin ortaya çıkmasını da, andlaşma koşullarında köklü değişmeler ilkesinin uygulanma gerekçesi olduğunu, 1977 Andlaşması yapılırken söz konusu olmayan ve öngörülmeyen bu durumun Viyana Andlaşmalar Hukuku Sözleşmesi 62. madde hükmünün uygulanmasını meşru hale getireceğini ileri sürmektedir. UAD bu iddiayı da reddetmiş ve 1977 Andlaşması'nın 15, 19 ve 20 madde hükümlerinin ${ }^{73}$, yeni ortaya çıkacak gelişmelere uyarlanmaya elverişli nitelikte olduğunu, bu durumun Andlaşmaya taraf olan devletlerin bu tür değişikliklerin ve gelişmelerin olabileceği yolunda öngörü sahibi olduklarının bir göstergesi olduğunu ileri sürmekte ve bu nokta itibariyle de, Macaristan'ın dayanaklarının temelsiz olduğu sonucuna varmaktadır ${ }^{74}$.

1969 Viyana Andlaşmalar Hukuku Sözleşmesi, uluslararası andlaşmaların sona erme koşulları içinde, "Koşulların Esaslı Biçimde Değişmesi" başlığ 1 altında, rebus sic stantibus ilkesine yer vermektedir. 62.madde hükmü, koşullarda meydana gelen köklü değişikliklerin sözleşmelerin sonlandırılabilme koşulu olabilmesi için, bu değişikliklerin "öngörülemez" nitelikte olmasını ve değişen bu koşulların tarafların iradelerinin oluşumunda "asli bir unsur" olarak yer almasını gerektirmektedir ${ }^{75}$. 62. maddenin kaleme alınış şeklinden rebus sic stantibus'a ancak çok istisnai hallerde ve sinırlı bir şekilde uygulanma olanağ1 verildiği anlaşılmaktadır. Doktrinde hakim görüş te bu yöndedir, rebus sic stantibus'un ancak istisnai hallerde ve bir hayli sınırlandırılmış olarak uygulanabileceğini dolayısıyla bu hükmün daraltıcı şekilde yorumlanması gerektiğini andlaşmalar hukukunda esas olan ilkenin ahde vefa yani pacta sund servanda olduğunu ileri sürmektedir. UAD nın Macaristan'ın 1977 Andlaşması'nın rebus sic stantibus ilkesi gereği hükümsüz hale geldiği iddiasına gerekçe olarak gösterdiği nedenlerin, "öngörülebilir" olduğu ve iradelerin oluşumunda "asli unsur olmadığı" ve ne tek tek ne de topluca Andlaşmanın geçersizliği için gerekçe olamayacağ yönündeki kararı, andlaşmalar hukuku kurallarıyla uygunluk içinde görünmektedir. Rebus sic stantibus koşulları ortaya çıkan durumlarda bile, buna dayanan tarafın söz konusu andlaşmayı otomatik olarak sona erdirmesi

\footnotetext{
731977 Andlaşması'nın 15, 19 ve 20 madde hükümlerinde su kalitesinin, doğanın ve balıkçılık haklarının korunmasına ilişkin hükümlere yer verilmektedir. UAD bu hükümlerin yeni ortaya çıkacak çevresel veya ekolojik koşullarla uyum sağlayacak bir esneklik içinde tasarlandığını, dolayısıyla çevreye ilişkin bilginin öngörülemez olduğu iddiasının tam aksi bir iddiayı haklı çıkaracak nitelikte olduklarını ileri sürmektedir. Divana göre bu hükümler tarafların Andlaşma hükümlerini uygularken bu tür gelişmeleri dikkate almalarını mümkün hale getirmektedir. ICJ Reports of Judgements 1997, prg. 104.

${ }_{75}^{74}$ ibid. prg. 104.

751969 Viyana Andlaşmalar Hukuku Sözleșmesi 62. madde hükmü için bkz. Gündüz, Aslan, (1998) Milletlerarası Hukuk, Temel Belgeler, Örnek Kararlar, Geliştirilmiş 3.bask1, Beta Yayınevi, İstanbul, s.198.
} 
kabul edilemez, doğru olan tutum andlaşmanın diğer tarafi ile yeni bir andlaşma yapılması veya uyuşmazlığı barışçıl yönden çözmek yönünde bir zemin arayışı içine girilmesidir ${ }^{76}$. Dolayısıyla Macaristan'ın tutumu ve ileri sürdüğü gerekçeler, rebus sic stantibus ilkesinin uygulanmasını gerektirecek ölçü ve etkinlikte değildir.

\section{DEĞERLENDİRME ve SONUÇ}

Tuna nehrinin Çekoslovakya ile Macaristan arasında kalan kesimi üzerinde bir dizi baraj yapma fikri, soğuk savaşın ilk yıllarına kadar uzanmaktadır. Özellikle Bratislava'daki endüstriyel yatırımlara elektrik enerjisi sağlamak, Sovyet Bloku için önemli bir gündem maddesi oluşturuyordu. Taşkınların önlenmesi de önemli bir sorun olarak ötedenberi gündemdeydi. Tuna' da dört mevsim kesintisiz bir ulaşım imkanı gerek ticari, gerekse askeri açıdan önem taşımaktaydı 1977 yılında her ikisi de sosyalist rejimle yönetilen ve Doğu Bloku üyesi olmak sebebiyle Sovyetler Birliği’nin nüfuz alanı içinde kalan Çekoslovakya ile Macaristan, iki taraflı bir andlaşma ile bu hayali gerçekleştirmeye yönelik ilk adımı atmışlardır. Büyük umutlarla başlatılan projenin neden olduğu çevre sorunları, daha işin en başında, Macaristan'ın tutum değişikliğine ve nihayet proje çalışmalarını tamamen bırakmasına yol açmıştır. Slovakya'nın projenin kendi kesimine düşen kısmındaki çalışmaları ise duraksamadan devam etmiş ve Gabcikovo barajı tamamlanmış daha sonra C Varyantı da devreye sokularak enerji üretimine başlanmıştır. Birbiriyle çelişen bu tutumlar tarafların projeye yönelik bakış açılarını yansıtmaktadır. Çekoslovakya ve ardılı Slovakyakalkınmadan yana teknomerkezci bir görüşü benimserken, Macaristan ekolojik merkezli yaklaşımını tüm süreç boyunca sürdürmüştür. Macaristan'ın istikrarla sürdürdüğü bu politika üzerinde, 1980lerde bu ülkede ortaya çıan çevrecilik hareketinin önemli etkisi olduğu görülmektedir. Macaristan'da sosyalist rejimin dönüşmesine aracıllk eden demokratikleşme hareketinin merkezinde yer alan çevrecilik hareketi, alternatif yaklaşımların ifade edilmesine olanak veren yegane meşru zemin olarak kabul görmüş ve kısa bir süre içinde rejime muhalefet eden hemen herkesi kendisine çeken bir olguya dönüşmüştü.

Gabcikovo-Nagymaros projesi ile ilgili olarak tarafların birbiriyle uzlaşması zaman içinde daha da zorlaşmış ve her iki tarafın da katı tutumu nedeniyle giderek artan tansiyon, uyuşmazlığın ancak bir arabulucu kanalı ile çözümlenebileceği bir noktaya gelinmiştir. $\mathrm{Bu}$ arabulucu, serbest pazar ekonomisi ve demokrasi ile yeni tanışan her iki devletin de, tam üyelik hayallerini süsleyen AT den başkası değildir. AT nin arabuluculuk girişimi,

\footnotetext{
${ }^{76}$ Pazarcı Hüseyin, (2001) I. Kitap, s. 19.
} 
uyuşmazlığın çok boyutlu ve karmaşık siyasi ve hukuksal boyutları karşısında soruna çözüm getirmemiş olmakla birlikte, tarafların UAD sürecine gitme yönündeki kararlarının oluşumu üzerinde etkili olmuştur.

Neredeyse 20 yıla yayılan bir süre ile tarafların gündemlerini meşgul eden bu sorunun UAD tarafindan ele alınması bir çok yönlerden bir ilki temsil etmektedir. Divanın, kuruluşundan bu yana ilk kez olarak, odağında çevre sorunları olan bir uyuşmazlık önüne gelmektedir. Bunun yanısıra sınıraşan sular sorunu bağlamında da bu uyuşmazlık Divan bakımından bir ilk uygulamadır. Divan yine ilk kez olarak bu davada delilleri yerinde inceleme ihtiyacı duymuş ve proje bölgesine teknik bir ziyaret gerçekleştirmiştir. Bu uyuşmazlıkta Divan'dan beklentiler yüksekti. Divan'dan sadece taraflar arasındaki uyuşmazlığı çözmekle yetinmeyip, bu dava vesilesiyle önüne çıkan bu ilk firsatı iyi değerlendirmesi, uluslararası çevre hukuku ilke ve standartlarını irdeleyerek açıklı̆ga kavuşturması beklenmekteydi. Çevre hukuku alanında oluşturulacak bir Divan içtihadı, bu alandaki örf ve adet hukuku kurallarının belirlenmesini sağlayacak ve bundan sonra ortaya çıkabilecek benzer nitelikteki uyuşmazlıklar ve uygulamalar için örnek teşkil edecekti. Beklenen olmadı. Divan bu konuda ihtiyatlı bir tutum içine girmeyi tercih etti. Divan dava sırasında sıklıkla gündeme gelen çevre hukuku ilke ve kavramlarının neler olduğu sorununu irdelenmekten çok, taraflara "ekonomik kalkınma" ile "çevre koruma önceliklerini" uzlaştırmak için işbirliği yapmaları yönünde genel tavsiyelerde bulundu. Diğer bir deyişle Divan, çevre hukukunun neredeyse merkezi kavramı haline gelen Sürdürülebilir Kalkınma ilkesine sadece genel bir gönderme yapmakla yetinmeyi ve konunun hangi denge içinde nasıl çözümlenebileceği konusunu, taraflara bırakmayı tercih etti.

UAD nın Gabcikovo-Nagymaros uyuşmazlığı çerçevesindeki tutumu ve davanın etkileri konusunda doktrinde olumlu olumsuz çeşitli görüşler dile getirilmiştir. Dava sürecinden çıkarılacak dersler anlamında gözden kaçırılmaması ve dikkate alınması gereken hususlar şu şekilde sıralanabilir. Birinci husus dava esnasında meydana gelen çevre zararlarına ilişkindir. Davanın UAD tarafindan incelendiği dört yıl boyunca, GabcikovoNagymaros proje bölgesinde, geriye dönüşü mümkün olmayan çevre tahribatı, durmaksızın devam etmiştir. Çevre sorunlarının niteliği gereği "zamanında" alınması gereken önlemler alınamamış ve mahkeme süreci sonunda durum çok daha olumsuz bir noktaya gelmiştir. İkinci olarak UAD bu davada taraflara bundan sonraki eylemlerini hangi hukuksal standartlara göre belirleyecekleri konusunda özel bir yönlendirme yapmak ve hukuksal bir reçete sunmaktan çok, tarafların bu uyuşmazlığ çözmek üzere biraraya gelmelerini, işbirliği ortamında sorunlarını çözmeye özen gösterecek şekilde müzakerelere devam etmelerini önermektedir. Bunun anlamı Divanın 
uyuşmazlığı çözememiş olduğu gerçeğidir. Dolayısıyla UAD kararını izleyen dönemde taraflar, müzakerelere devam etmek durumundadırlar, nitekim böyle de olmuştur. Müzakereler esnasında Divan'ın vermiş olduğu kararın, uyuşmazlığın çözümü yönünde olumlu katkı sağlayıp sağlamadığ 1 sorusu sorulduğunda ise, yanıt pek de olumlu görünmemektedir. UAD kararında, farklı nedenlerle de olsa, hem Macaristan hem de Slovakya'nın uluslararası hukuku ihlal ettikleri sonucuna varmıştır. Dolayısıyla her iki tarafın da Divan kararında arkalarını dayayabilecekleri sağlam gerekçeleri mevcuttur. Bu durum ise, uyuşmazlığın çözümünü kolaylaştırmaktan çok, tarafların kendi katı pozisyonlarını mahkeme kararını da arkalarına alarak sağlamlaştırmaları ve böylece tüm müzakere sürecini bloke etme imkanlarını artırmak gibi bir risk taşımaktadır. Üçüncü husus, UAD kararlarının uygulanma süreçlerinin takibinin yapılmıyor olmasıyla ilgilidir. UAD nın vermiş olduğu mahkeme kararlarını izleme ve denetleme olanağı bugünkü uluslararası hukuk sisteminde mevcut değildir. Mahkeme kararlarının uygulanmaması durumunda ortaya çıkabilecek ihtilafların çözümlenmesi için taraflarca herhangi başka bir yöntem benimsenmemişse, her zaman için UAD na yeni bir başvuru yapmaları gereklidir. Böyle bir olasıllk, uzun vadede sorun çözücü bir olanak gibi görünse de, yol açacağı zaman kaybı, doğası gereği buna toleransı olmayan çevre sorunları bakımından hiç de istenen bir durum değildir. Durum kendisine yönlendirilen bir uyuşmazlığ çözmek gibi bir görev tanımı olan Divan bakımından da başarısızlık olarak algılanabilir, dolayısıyla anlamlı değildir.

Tüm bu hususlar birlikte değerlendirildiğinde, çevre uyuşmazlıklarının çözümü için uluslararası yargısal süreçlere gidilmesinin uygun bir zemin olup olmadığı sorusunun, ciddi tereddütleri de beraberinde getirdiği görülür. UAD nın Gabcikovo-Nagymaros uyuşmazlığı sürecinde takındığ 1 ve zorunlu olmadıkça pek de değişmeyecekmiş gibi görünen ihtiyatlı tutumunun nedeni, belki de budur.

\section{KAYNAKÇA}

BOSTIAN, Ida (1998): "Flushing the Danube: The World Court's Decision Concerning the Gabcikovo Dam", Colorado Journal of International Law and Policy, vol.9:2, s. 401-427.

ECKSTEIN, E. G. (1995): "Application of International Water Law to Transboundary Groundwater Resources and the Slovak-Hungarian Dispute Over Gabcikovo-Nagymaros", Suffolk Transnational Law Review, Volume 19, s. 67-105.

ECKSTEIN, E. G./ECKSTEIN, Y. (1998): "International Water Law, Groundwater Resources and the Danube Dam Case", paper and presentation for International Association of Hydrologists XXVII Congress and Annual 
Meeting of the American Institute of Hydrology, Las Vegas (Sept.27-Oct. 2), Brahana et.al (eds.) Gambling with Groundwater-Physical, Chemical and Biological Aspects of Aquifer-Stream Relations, s. 243-248. http:// www.internationalwaterlaw.org/Bibliography/Gabcikovo.html (12 Nisan 2006 tarihi itibariyle).

FUYANA, B./MADAI, F. (2001): "The Hungary-Slovakia Danube River Dispute:Implications for Sustainable Development and Equitable Utilization of Natural Resources in International Law", International Journal of Global Environmental Issues, Vol. 1, Nos.3/4, s. 329-344.

FÜRST, Heiko (2004): "The Hungarian-Slovak Conflict over the GabcikovoNagymaros Dams: Analysis", Institute for Peace Research and Security Policy, University of Hamburg, Germany. s. 1-15 http://www.internationalwaterlaw. org/Bibliography/Gabcikovo.html (30 Mayıs 2006 tarihi itibariyle).

GÜNDÜZ, Aslan (1998): Milletlerarası Hukuk, Temel Belgeler, Örnek Kararlar, Geliştirilmiş 3.baskı, Beta Yayınevi, İstanbul.

GÜNEŞ, Şule (2001): "Karadeniz'de Çevresel İşbirliği, 1992 Bükreş Sözleşmesi", ODTÜ Gelişme Dergisi, Cilt 28, Sayı 3-4, s.311-337.

HIGGINS, Rosalyn (2001): "Natural Resources in the Case Law of the International Court", Boyle Alan -Freestone David (eds.), International Law and Sustainable Development, Oxford University Press, s.87-112.

PAZARCI, Hüseyin (1999): Uluslararası Hukuk Dersleri, III.Kitap, Gözden Geçirilmiş 3.baskı, Ankara, Turhan Kitabevi.

PAZARCI, Hüseyin (2001): Uluslararası Hukuk Dersleri, I.Kitap, Gözden Geçirilmiş 9. baskı, Ankara, Turhan Kitabevi.

SCHAPIRO, Mark (1997): "Unquiet Flows the Danube, Hungary Sues Slovakia Over Hydroelectric Project”, NATION, March 10, 1997.

STEC, S./ECKSTEIN, E.G. (1997): “Of Solemn Oaths and Obligations: The Environmental Impact of the ICJ's Decision in the Case Concerning the Gabcikovo-Nagymaros Project", Yearbook of International Environmental Law, Volume 8, Clarendon Press, s. 41-51.

STEC, Stephen (1999): "Do Two Wrongs Make a Right? Adjudicating Sustainable Development in the Danube Dam Case", Golden Gate University Law Review, Vol. 29, s.317-397.

TOLUNER, Sevin (2000): Milletlerarası Hukuk Açısından Türkiye’nin Bazı Dış Politika Sorunları, Beta Yayınları, İstanbul.

TOMKA, P./ WORDSWORTH, S. Samuel (1998): “ The First Site Visit of the International Court of Justice in Fulfillment of Its Judicial Function" American Journal of International Law, Vol. 92, No.1, s. 133-140.

- Danube Dilemma: Hungary and Slovakia to Square Off at the Hague, s.1-3 http:/greenhorizon.rec.org/bulletin/Bull64/cover.html (12 Nisan 2006 tarihi itibariyle). 
Major Events in Slovak History: http://www.slovakia.org/historysummary.html (20 Mayıs 2006 tarihi itibariyle).

\section{BELGELER}

\section{GENEL OLARAK}

Lanoux Nehri Kararı: Lac Lanoux Arbitration, Reports of International Arbitration Awards (RIAA), vol.XII, Decision of 16 November 1957, s. 285-317.

Meuse Nehri Kararı: Diversion of the Water of the Meuse (Judgement),1937, Permanent Court of International Justice (PCIJ), Ser.A/B, No 70.

Oder Nehri Kararı: Territorial Jurisdiction of the International Commission of the River Oder, 1929, PCIJ, Ser.A, No 23.

Tuna'da Ulaşımın Düzenlenmesine İlişkin 1948 Tarihli Andlaşma: Convention Regarding the Regime of Navigation on the Danube, August 18, 1948, United Nations Treaty Series, 197.

\section{GABCIKOVO-NAGYMAROS UYUŞMAZLIĞINA İLIŞKİN BELGELER}

1977 Andlaşması: The Treaty Between the People's Republic of Hungary and the Socialist Republic of Czechoslovakia on the Construction and Joint Operation of the Gabcikovo and Nagymaros System of Locks, Signed in Budapest on 16 September 1977 http://www.gabcikovo.gov.sk/doc/it1977en/treaty.html (12 Şubat 2006 tarihi itibariyle).

1992 Tarihli Macaristan'ın 1977 Andlaşmasını Fesih Bildirimi: Declaration of the Government of the Republic of Hungary on the Termination of the Treaty Concluded Between the People's Republic of Hungary and the Socialist Republic of Czechoslovakia on the Construction and Joint Operation of the Gabcikovo and Nagymaros Barrage System, Signed in Budapest on 16 September 1977, May 19, 1992, 32 ILM (1993) 1247-1260.

1993 Tarihli Tahkimname: Special Agreement for Submission to the International Court of Justice of the Differences Between the Republic of Hungary and the Slovak Republic Concerning the Gabcikovo-Nagymaros Project, April 7, 1993, http://www.gw.ace.hu/ddg/haga/english/e_spec.htm (11Mart 2006 tarihi itibariyle) ayrica bkz. (1993) 32 ILM, 1293-1295.

Gabcikovo-Nagymaros Karar1: ICJ Reports of Judgements 1997, Case Concerning the Gabcikovo- Nagymaros Project, Hungary vs. Slovakia, (25 September 1997), http://www.icj-cij.org/icjwww/idocket/ihs/ihsjudgement/ihs_ijudgement _970925.html (18 Kasim 1999 tarihi itibariyle). 